\title{
Carlos Saldanha's Cinematic Reinvention of Rio as An Aspiring Global City
}

\author{
Else R. P. Vieira, ${ }^{1}$ Queen Mary University of London, United Kingdom
}

\begin{abstract}
This article analyzes Rio de Janeiro's bravura reinvention as an aspiring global city by examining Carlos Saldanha's 2011 "Rio", conceived during the city's, and Brazil's, economic euphoria, and when animations were benefiting from major technological advances in production and distribution. The blockbuster shares redeployments of Rio's negative image with other media campaigns in the run-up to the 2014 FIFA World Cup and 2016 Summer Olympics. Its seemingly simplistic plot represents global issues and references the urban imagery developed by the US Good Neighbor Policy's mass tourism and media initiatives (1930s-1940s), particularly Disney's animations and Freeland's "Flying Down to Rio." Saldanha's ambivalent affective geography may foster tourism but reinstates the policy's North-South asymmetries against the grain of landmark challenges of power hierarchies by emerging BRICS countries and the G20. The movie's infelicities amidst the inherently laudable inclusion of a social plot, correlating with Global South urban geopolitics, are assessed.
\end{abstract}

\section{Keywords: Carlos Saldanha's “Rio”, Good Neighbor Policy, Global South Cities, Olympics}

$\mathrm{T}$ This article analyzes the ways Rio de Janeiro-born and New York-resident director Carlos Saldanha combines aesthetics, marketing strategies, and geopolitics in his multimillion blockbuster Rio, a 2011 animation produced by Blue Sky Studios and intended as a love letter to his hometown in the run-up to the 2014 FIFA World Cup and the 2016 Olympiad and Paralympiad. It initially contextualizes Rio as an emerging global city hosting the three megaevents, made possible by successful bids in the heat of the city's, and Brazil's, economic upsurge and rising profile after a period of decline and economic crisis. The article thus correlates Rio's hosting of these mega-events with the city's rehabilitation of its image as part of the process of becoming global within the broader context of major geopolitical shifts. These include the formation of an alliance of emerging economies known by the acronym BRICS (Brazil, Russia, India, China, and South Africa) and the broadening of the G7 grouping of hegemonic countries into the G20. Neologisms, such as competitive urbanism, and reconceptualizations of two particularly unstable terms, "global cities" and "cinematic cities" (Andersson and Webb 2016), reflect these global repositionings.

The article also explores the ways that Saldanha's 3D computer-generated animation, benefiting from landmark technological developments for film production and worldwide distribution, creates a spectacle of Rio as a cinematic global city, sharing with various other campaigns a redeployment of the city designed to change its negative image and project an upcoming and welcoming one (Denslow 1997). The first part explores Global North/South cultural issues through Saldanha's reliance on what Canelo (2014) has referred to as the visual knowledge and cinematic strength established for Rio by the 1933-1945 Good Neighbor Policy (hereafter GNP). The GNP was a political, cultural, economic, and promotional Pan-Americanism project, developed by President Franklin Delano Roosevelt via the Office of the Coordinator of InterAmerican Affairs (OCIAA), a US government agency directed by Nelson Rockefeller for strengthening the military, technological, and economic bonds of collaboration among the continent. The initiative included a line of movies designed to stimulate continental solidarity (Schwarcz and Starling 2015) and to redefine Americans' perceptions of Latin America for marketing and mass tourism purposes. An analysis of Thornton Freeland's GNP-sponsored

\footnotetext{
${ }^{1}$ Corresponding Author: Else Vieira, 327 Mile End Road, Department of Modern Languages and Cultures, Queen Mary University of London, London, E14 NS, United Kingdom. email: e.vieira@qmul.ac.uk
} 
airborne musical Flying Down to Rio (1933), produced by Merian Cooper, a founding member of the Board of Directors of Pan Am, brings out the movie's marketing of mass tourism; the airline connects this South American city, boasting privileged views from above, to the world. This paves the way for the analysis of the ways Saldanha's musical draws upon conjoined flights and aerial views to promote Rio's Olympic urbanism and develop a tourism-oriented ecological plot. An undertone of desire, shared by both Freeland's and Saldanha's movies, is analyzed.

Saldanha may also have learned from the GNP that motion pictures, particularly those originating in the US, provided a direct approach to the widest audiences in the hemisphere (Canelo 2014). Therefore, the article analyzes Saldanha's reliance on the foremost Hollywood producer of animations for the GNP, Walt Disney, motivated by his alleged need to project a vibrant Brazil. As a counterstatement to over-projected violence and criminality, Saldanha's movie emphasizes the sense of happiness that his hometown can bring to its citizens (the Cariocas) and tourists. Overall, Saldanha's referencing of the Policy recreates a very positive urban imaginary for Rio, with a great potential for boosting mass tourism via blockbusters, however, at the same time, it reaffirms anachronic North-South hierarchies and recasts Brazil in the periphery of global capitalism. As such, the movie goes against the grain of history and, particularly, the BRICS's and the G20's upturning of West-driven hegemonic structures of capitalism

The article's second part analyzes ways Saldanha redresses the Policy's and the Olympic bid book's exclusive focus on hedonism and omission of poverty, by introducing favela [slum] scenes, a social plot and a wider range of precariously integrated social actors, such as an orphan favela boy and a plethora of malandros (literally, tricksters or rogues). This broader social spectrum is symptomatic of persisting social, economic and racial inequalities, and little social mobility in a city that was, at the time, the world's thirtieth wealthiest. The animation, however, neutralizes social tensions in several ways. The racialization of crime and poverty tourism-slanted scenes are some of Saldanha's infelicities in his deployment of downsides, amidst overall improvements, in this South American metropolis competing for global urbanism through mega-events.

Rio's selling points were particularly underscored in many of the mega-events' bid videos and as many as 96 foreign movie productions that were almost fully shot in the city in 2011 . The Olympic project required creating an enticing visual narrative for a city that, since the 1980 s, had been increasingly depicted in the media headlines as a "metropolis of social implosion, brutal inequality, and tremendous violence wrought by the drug trade" (Jaguaribe and Salmon 2016, 3839). Neofavelas (neglected communities occupied by armed drug dealers) had also been the powerful focus of international box office hits like City of God (Meirelles 2002) or Elite Squad (Padilha 2007)

Leslie Marsh (2012) stressed the vitality of films about Rio in the landmark year of 2011, a context in which Saldanha's animation was the second most-seen film in Brazil and the tenth highest box office earner worldwide. For him, "the film's one-word title boldly asserts that it aims to present a place," Rio, which, due to Hollywood's renewed interest, has earned the nickname "Riollywood" $(2012,74)$. The focus of Marsh's first foray into Rio's revisitations of GNP tropes is on Latin Americans' sexual freedom and on the Southern continent as a place for Anglo-Saxon tourists to enjoy erotic passions with locals. His conclusion challenges Rio's categorization as a Brazilian movie. Despite Saldanha at the helm, Rio is "Brazil branded by Hollywood to fulfill cultural expectations outside the country" $(2012,74)$.

This article's comparative analysis between the GNP and the contemporary views of the city projected by the under-studied blockbuster Rio goes well beyond Marsh's focus on eroticism and conclusion related to the identity of national cinemas. It stresses the ways Saldanha updates the GNP-derived visual knowledge of Rio to re-present and promote global tourism to his hometown in the run-up to the mega-events that were indeed a major element in the city's economic revival and claim to global status. "Rio é alegre, Rio é feliz" ["Rio is cheerful, Rio is happy"] (Saldanha in Koche 2011, n.p.). He further refers to his celebratory endeavor: 
The movie was like a love letter to my city... I'm Brazilian and I've always seen movies about Brazil or Rio that I didn't connect with. This project started with the need to show a different Brazil, a Brazil closer to me, it's a happy vision, a more colorful vision, a musical vision that really represents Brazil” (In Fridmann and Moreno 2014, n.p.).

The notion of branding - the "aggressive marketing and promotion strategies to sell cities in response to the imperatives of neoliberal competitive urbanism"-was compellingly used by Beatriz Jaguaribe and Salmon Scott, experts in communications and visual cultures, to demonstrate that the Olympic Games were intended to open perspectives for Rio to raise its profile beyond contradictory media projections of a hedonistic tropical city and "a metropolis of social implosion, brutal inequality, and tremendous violence wrought by the drug trade" (2016, 31). This perception weaves this article's further argument that Saldanha's love letter goes beyond reinventing his hometown symbolically in the global imaginary. His imagineering of his hometown can also be said to partake in the 21 st century marketing of Rio as a prospective host city to global audiences and, particularly, the North American.

\section{Rio as a Global City on the Rise, the Mega-Events, and the BRICS}

Rio's protean profile as homeland to major world events had been rising since the 1970s with the Brazilian Grand Prix (1978-1990), the series Rock in Rio (1985-), the world's biggest entertainment event, and the United Nations Earth Summits (Russell and Cohn 2012). However, the city's international profile declined due to the country's hyperinflation in the last quarter of the $20^{\text {th }}$ century. ${ }^{2}$ The tide changed again in the early $21^{\text {st }}$ century, and Rio, having benefited from the energy sector and mining boom, became Brazil's second richest city, playing a pivotal role in the country's euphoric economic renewal. ${ }^{3}$ Its rising urban competitiveness and claim to the lowest unemployment rate among the world's large cities attracted global enterprises and a high-skill workforce (Fontaine 2016). Signaling the city's renaissance, Rio was center stage for several heavily publicized mega-events, notably the FIFA World Cup final in $2014 .^{4}$

Rio particularly rose to international stardom as an aspiring global city (see below) when, on October 2, 2009, after a successful campaign and an intensive bidding, it was the first South American city to be selected by the International Olympic Committee as the host city for the 2016 XXXI Olympiad and the XV Paralympiad. Rio outmatched one major global city, Tokyo, and two globalizing ones (see Rennie-Short's categorization below), Chicago and Prague. ${ }^{5}$ For Beatriz Jaguaribe and Scott Salmon (2016), the Olympics created a window of opportunity for Rio to project itself as an emerging power in a volatile global context. The sobriquet Cidade Maravilhosa [Marvelous City], ${ }^{6}$ which recalls Rio's natural exuberance, underlay another successful bid to

\footnotetext{
${ }^{2}$ Before this, Rio had gradually lost its status as the country's financial and commercial hub to ever-rising São Paulo; its decline was aggravated by regressive deindustrialization of key sectors like steel and shipbuilding and the decreasing public sector with the 1960 transfer of Brazil's capital from Rio to Brasília

${ }^{3}$ Rio particularly benefited from the energy-sector and mining boom. Alongside the mining conglomerate Vale, equally Rio-based petroleum giant Petrobrás (Brazilian Petroleum) had announced that Brazil would be energy self-sufficient and one of the world's top five oil producers and had grown its operation around the Guanabara Bay, including a university research center on the Ilha do Fundão (Williams, Chazkel, and Mendonça 2016, 242-243).

${ }^{4}$ Other mega-events, including the Pan American Games in 2007, the World Military Games in 2011, World Catholic Youth Day with Pope Francis in 2013, and the city's celebration of its $450^{\text {th }}$ anniversary, reinforced Rio's international reach and projected the cosmopolitanism of its business sector.

${ }^{5}$ Other prominent competing cities include Madrid, Baku, and Doha (Russell and Cohn 2012).

${ }^{6}$ The sobriquet Cidade Maravilhosa, crystallized in Rio's official anthem and derived from its stunning topography, was first used in a 1935 Carnival song about the city in its heydays, composed by André Filho, titled "Marvelous City," which hit the airwaves and has ever since "acquired an aura of foundational myth" (Carvalho 2016, 21).
} 
include its "dramatic landscape" and "staggeringly beautiful location" on the UNESCO World Heritage List (2012).

“Aspiring global city," an expression used by Jaguaribe and Salmon (2016) for pre-Olympic Rio, both references and repositions Saskia Sassen's (2011) landmark conceptualization of global cities as a phenomenon of the 1980s, based on paradigmatic London, New York, and Tokyo. For Sassen, what specifies a global city is the concentration of transnational corporations' headquarters, commanding production activities scattered around the world. Several scholars thereafter broadened the notion of global cities beyond Sassen's top echelon. Process-oriented concepts such as "globalizing cities" (Rennie-Short 2004, 21) were introduced. Others claimed international recognition of global city status for cities that may not have full control of the world's economy but perform other prominent global functions, such as promoting attractive global tourist environments (Robinson 2002).

Rio's rising status in urban geopolitics can be situated within the broader historical field of the reorganization of the world's economy and power hierarchies in 2008-09. These watershed years of banking crisis and recession in the Northern hemisphere inaugurated a new globalization cycle that gave rise to increasingly influential cities in the world's emerging economies. As evidence that the world was becoming more polycentric since Sassen's ground-breaking intervention (Andersson and Webb 2016), the 2008 Global Cities Index included Rio and São Paulo in its list of 60 cities in the world that most shape our lives and excel across multiple dimensions (business, politics, engagement, human capital, information exchange, and the cultural experience of diversified attractions for travelers and major sporting events). The wave of optimism surrounding this recalibration process included the first meetings of the BRICS alliance (Sarkar 2014) and the emblematic expansion of the G7 countries into the more inclusive G20 (Cervo 2008). ${ }^{7}$

The BRICS countries' hosting of mega-events, according to the expert in the economics of sports, Andrew Zimbalist, is "a sort of coming out party signaling that it is now a modernized economy, ready to make its presence felt in world trade and politics" $(2015,23)$. For Jaguaribe and Salmon, mega-events "offer unprecedented opportunities for cities to revalorize themselves through symbolic as well as material reinvention" and to establish their brand with a truly global audience (2016). For Rennie-Short (2004), an expert in urban issues, the Olympic Games are an important platform for place marketing for cities seeking global city status. Terms such as "urban imagineering" (Rennie-Short 2004, 24; Jaguaribe and Salmon 2016, 31) were incorporated into the globalizing city jargon as these cities increasingly sought to reposition themselves in the discursive space of urban imagery (Rennie-Short 2004).

\section{Rio as a Global Cinematic City in the Run-up to the Olympics}

Rio's international profile has been largely shaped by cinema. The run-up to the mega-events reinstated its uncredited role as a cinematic city-defined as cities that have a significant film industry and whose identities have been particularly projected by film (Shiel and Fitzmaurice 2001) — a label often associated with Los Angeles, New York, London, and Paris. Contributing to a plethora of fluctuating terms, Johan Andersson and Lawrence Webb have advanced the notion of "global cinematic cities," which repositions the study of cinematic cities beyond the established ones in the US and Europe as well as above hierarchical North/South binaries (2016). They have, for example, added Buenos Aires, but failed to include ever-projected Rio in their collection of studies on the shifting panorama of global cinematic cities. It was Saldanha's achievement to put Rio on the map of global cinematic cities.

Saldanha's blockbuster bears the marks of production in the 2009 euphoria when the metropolis was preparing for the three major mega-events. The animation's establishing scene

\footnotetext{
7 "In the financial arena, the G20 ... was created as a response to the financial crises of the late 1990s and in recognition of the fact that key emerging-market countries were largely excluded from global economic governance" (Roett 2011, 138).
} 
visually alludes to the city's resurgence. The movie opens at dawn, with an aerial shot of the still sleepy iconic Guanabara Bay. The camera gradually moves away from the coast toward the lush vegetation on the mountains where a small colorful bird (0.50) flies freely from tree to tree at dawn waking up the other birds; a new day is born, and the city comes to life as a visual spectacle.

Saldanha's movie has been particularly credited for having made a superb combination of new technology and skill in stamping his reinvention of Rio's image with the insider's seal of authenticity. The world's most screened Brazilian cineaste (born 1968) had spent half of his life in Rio, before settling in the US in 1991, where he was invited to work for Blue Sky Studios, the animation branch of Fox Corporation. His timing was fortunate because of the dramatic increase, since the 1990s, in demand for animation talent in the context of cutting-edge computer technologies, proliferating cable and satellite television channels, and a boom in adults' interest in animation. His artistry and robust Brazilian degree in computer science found fertile soil in the US. Unsurprisingly, his blockbuster Rio harnessed over 487 million dollars at the world's box offices (The Numbers 2011) and ten award nominations with two wins.

Ecology, sharpened class divides, criminality across borders, and poverty tourism are some of the topical global issues embedded in the film's apparently simple plot. The movie begins with the Rio-born male blue macaw named Blu, still a baby, plucking up the courage to step outside his nest in Rio's urban forests when he was traumatically caught by bird traffickers, then abandoned in cold and snowy Minnesota, where he was adopted and nurtured by the protective Linda Gunderson (Figure 1).

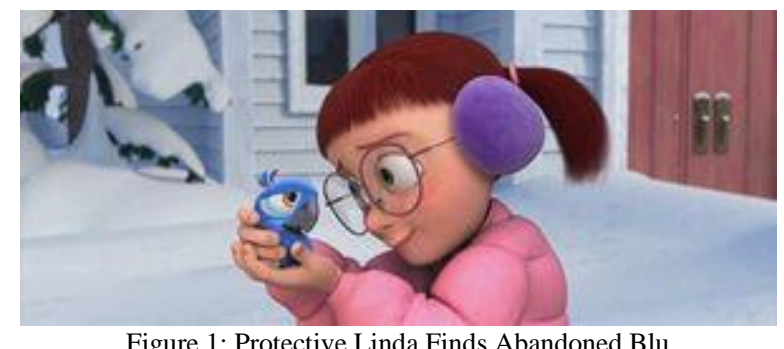

Figure 1: Protective Linda Finds Abandoned Blu Source: Fandom Rio 2014

Domesticated Blu forgets how to fly. Fifteen years later, Brazilian ornithologist Túlio visits Linda in Minnesota and convinces her that Blu, the last male of a highly endangered species, needs to be taken back to Rio to mate with his female counterpart, Jewel. Albeit reluctantly, she accepts Túlio's ecological endeavors to correct the ill effects of the smuggling of exotic birds. The vibrant Carnival parade is the setting that marks the beginning of the couple's adventure in Rio and the plot's suspenseful climax. While Túlio and Linda are having dinner, they leave Blu and Jewel in a large cage in the laboratory where the ornithologist keeps hundreds of birds rescued from smugglers. However, these criminals break in, steal Blu and Jewel, and hide them in a favela. Other birds and animals help the chained birds escape. Nigel, an ugly and evil cockatoo, chases the rare birds during Carnival. With the guidance of Fernando, a good-hearted and guilt-ridden orphan boy from the favelas, Túlio and Linda recover the two birds. Fernando's fate thus intersects with Túlio's noble work of protecting endangered species and Linda's righteousness, both counteracting international bird trafficking.

In keeping with animations' presumed audience of children (albeit not exclusively), order is restored with the dealers being thrown in jail. Saldanha guides the plot to finish with a happy ending. With the help of a friendly toucan, Rafael, Blu overcomes his fear of flying and finds his way back to Linda. Túlio and Linda adopt Fernando, who gains a family and escapes social disadvantage and favela life and stays in Rio.

\section{Rio and the GNP: Film, Flying, Eroticism, and Mass Tourism}


This section explores ways Saldanha draws upon the visual knowledge and stereotypes created for Rio by the GNP, in his attempts to rehabilitate Rio's image and to restore its top tourist attractions to their former glory in the run-up to the mega-events. A particular focus is on his marketingoriented updating of the GNP's bridging of motion pictures, aviation, and eroticism to promote mass tourism.

\section{The GNP's Visual Knowledge and Saldanha's Marketing of Rio's Ecotourism}

Two life-changing inventions, aviation and motion pictures, helped to spur the GNP's globalization of mass tourism, in turn, becoming a powerful instrument of the expansion of American hemispheric influence in the 1930s and 1940s. One key player was Pan American Airways. The second was the movie production and distribution company RKO, one of five GNP-related studios of Hollywood's Golden Era, intended to promote unity with Latin America and provide a prime market for America's film exports (Mehr 2000). Flying Down to Rio (1933), one of Rockefeller's investments in South America (Schwartz 2004), anticipated the 1939-47 wave of PanAmericanism-themed musicals produced and distributed by RKO. This dazzling movie, first advertised as a "romantic adventure that crosses the skies at great heights," capitalizes on the human dream of flight and the sense of exhilaration while flying, when panoramic views of a city from above were a great novelty (Figure 2).

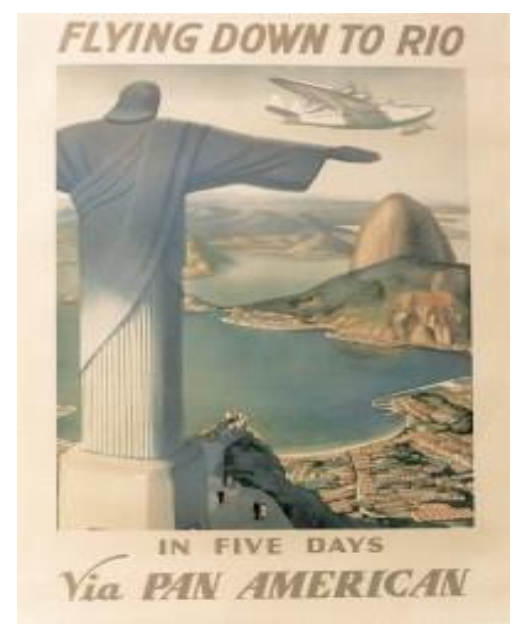

Figure 2: Poster-Flying Down to Rio in Five Days Via Pan American Source: International Poster Gallery 1939

Saldanha's movie, nowhere short on mass tourism orientation, updates the GNP's visual knowledge of Rio as a cinematic spectacle from above into Olympic urbanism. He draws heavily upon Hollywood's standards for aerial views, flight imagery, and the discovery of Brazil by a stunned foreigner in the 1930s. His ingenious replacement of the clipper in Flying Down to Rio with a hang-glider simultaneously serves major Olympiad marketing functions: it underscores a sports-focused population, a healthy outdoor lifestyle, and a sustainable tourist activity, all themes dear to the global agenda. A distinctive trait of Rio is the aerial view of a precious but underpublicized facet of the city, ecotourism within a metropolis. Indeed, Rio is home to two of the world's largest urban forests, the Pedra Bonita and the Tijuca forest. Pedra Bonita is a natural habitat for more than 200 species of exotic birds and has been a national park since 1961. The Tijuca forest is where the statue of Christ the Redeemer sits atop a hill (Figure 3). 


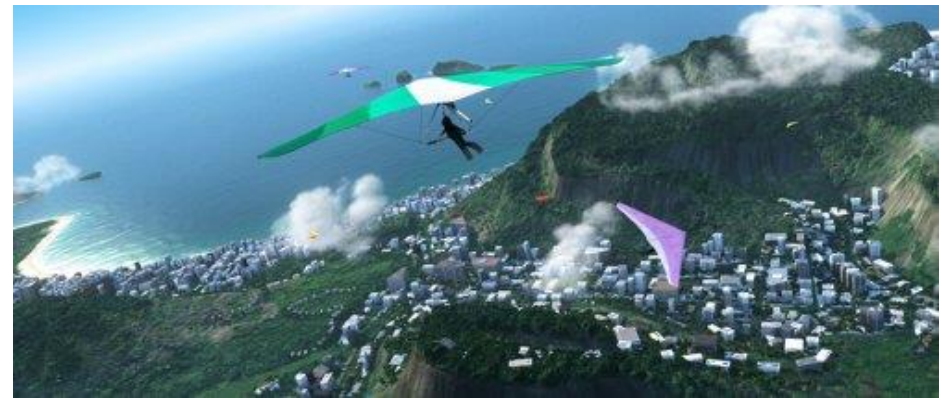

Figure 3: View of Rio's Urban Forests from a Hang-Glider Source: NA.SSI Images 2011

It is from the 1024-meter-high Pedra Bonita peak that the hang-gliders set out. The Cariocas' particularly developed sporting ability contrasts with flightless Blu. This Americanized male macaw, perched on a hang-glider flying over the urban forests before landing on the São Conrado beach, looks over the arresting topographical beauty of such a vast city and exclaims, in an echo of the Cidade Maravilhosa: "this is the most beautiful thing I've ever seen" (Figure 4).

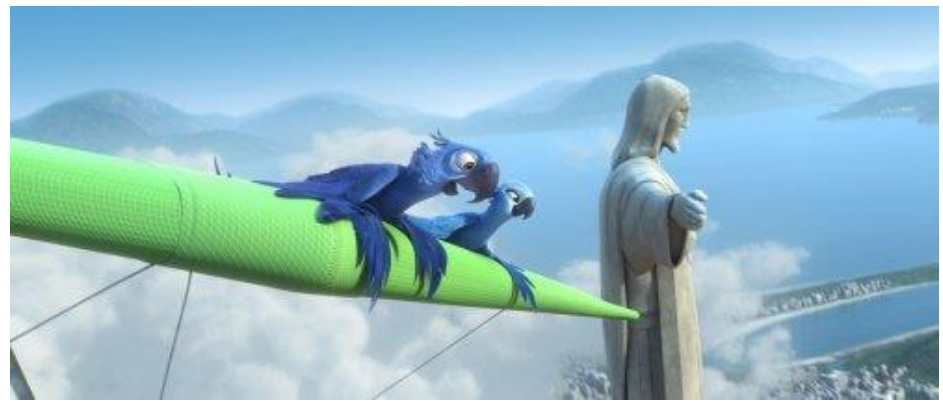

Figure 4: Blu on the Most Beautiful Thing He Has Ever Seen Source: Veja Magazine 2011

Saldanha's choice of having most of the characters as birds, besides doing justice to Rio's urban fauna, greatly widens the possibilities of visualization of the city from above and the landscape that has made Rio a United Nations World Heritage site. His Disney-reminiscent display of exotic birds in the initial scene also includes a small, innocent-looking, yellow bird sitting in a tall tree overlooking the near-magic of Rio's scenic combination of vast stretches of sandy white beaches, granite rocks, and tropical forests as if offering an invitation for the world to experience this visual spectacle. From the hang-glider, the birds best capture other signature landmarks, particularly Rio's iconic Guanabara Bay and the Sugar Loaf (Figure 5). 


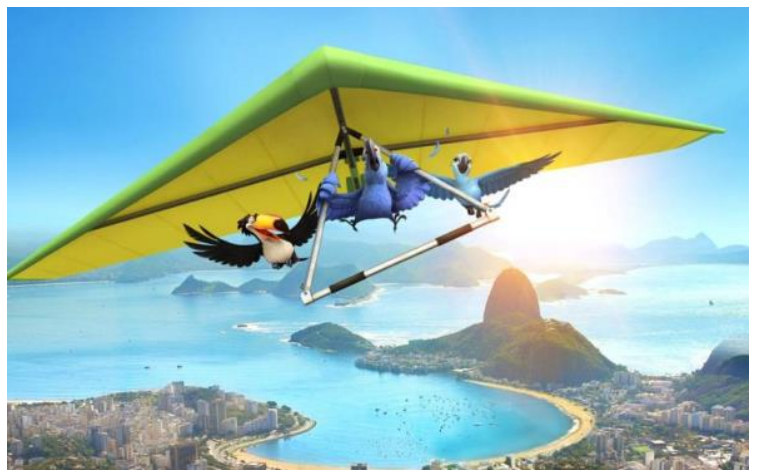

Figure 5: The Birds' Aerial View of Rio's Iconic Guanabara Bay and the Sugar Loaf Source: Veja Magazine 2011

\section{The GNP's Stereotypes Quoted: Marketing Technology and Desire}

Saldanha further draws upon the GNP's amalgamation of flight and desire to boost mass tourism, notably the airborne extravaganza Flying Down to Rio. This movie has been "credited with the most hallucinating moment in the history of Rio in film: the great aerial musical number above the spectacular landscapes of Rio" (Rodrigues 2008, 169) (Figure 6).

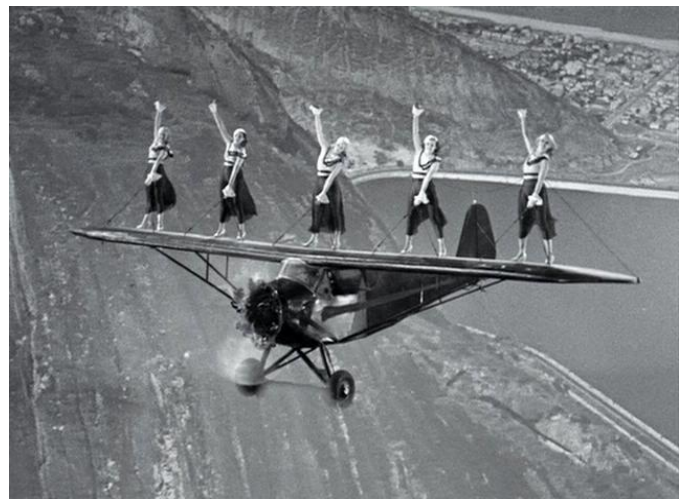

Figure 6: Flying Down to Rio in Airplanes

Source: Finishung n.d.

The dream of flying over Rio's cinematic spectacle further intersects with the establishment of a reputation of something unique about Brazilian women. For example, one of the American girls wondered, "What have these Brazilians got below the equator that we haven't?" 8 Subliminally, Flying Down to Rio reinstates North/South hierarchies; the US provides technology (the airplane and the motion picture) and the South the sexualized body. The 1930s movie further builds an erotic crescendo as the plane begins to descend, and twenty-two high-heeled and increasingly under-dressed chorus girls, tethered to the wings of the airplane, begin dancing (Figure 7).

\footnotetext{
${ }^{8}$ Flying Down to Rio reverberates in Marsh's character analysis: "As an unattached female who dislikes leaving her home, Linda seems to present her own threat to the survival of the human species. Fortunately, all she needs is a little time below the equator to bring out her sensuality" $(2012,75)$.
} 


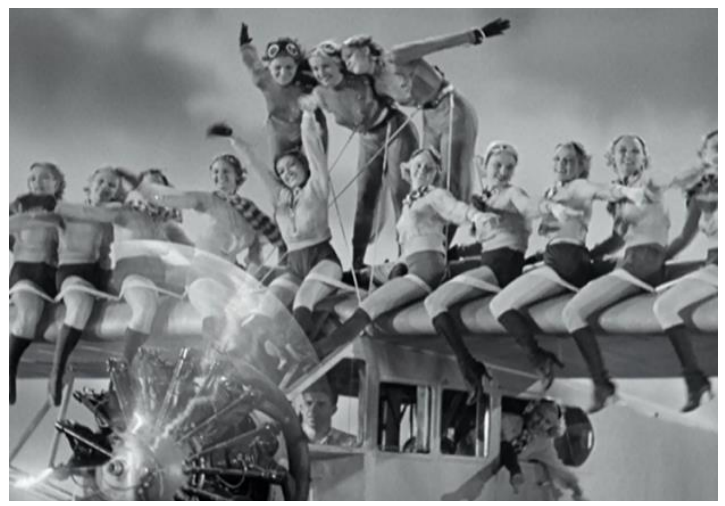

Figure 7: Aviation and Desire in Flying Down to Rio Source: Ronald Grant Archive / Alamy Stock Photo 1933

As part of the GNP's view that pleasure, joy, and friendliness were fundamental for North/South relations, the technologies of visibility used by the policy also turned Brazil into a stereotype of exotic and sexy bodies. The intention was to create imagery of seduction for the US viewer by correlating South America to characteristics associated with the desirable and feminine (Canelo 2014). ${ }^{9}$

Accordingly, Saldanha draws upon the market-oriented sexual stereotypes popularized by the GNP and projects the sensuality and exuberance of the Carioca woman. ${ }^{10}$ The use of this stereotype also reaffirms what Laura Mulvey (1989) has theorized as cinema's tendency to objectify women on screen, often with the intent of satisfying a male heterosexual spectator. Jewel flies like a winged Venus, and her curvy and most sensual body becomes an object of desire for bedazzled Blu. In this scene, the plot of procreation for the preservation of a rare species shifts into desire (Figure 8).

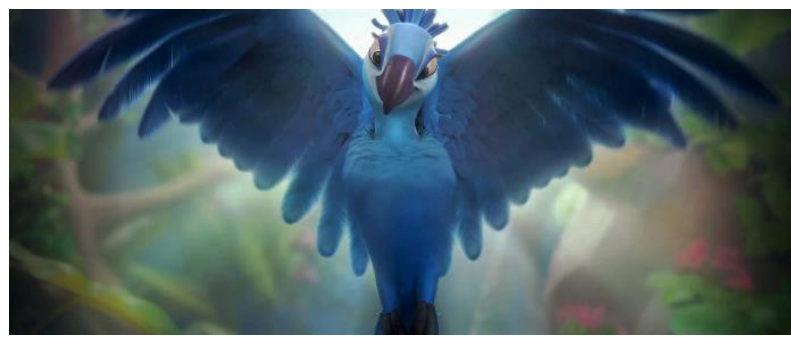

Figure 8: Jewel as an Object of Desire Source: Fandom Rio 2014

Jewel, however, upturns the male gaze and patriarchal hierarchies by controlling the objectification of her body. She dominates the camera, the pace of the scene of the encounter, and Blu's gaze, granting herself ownership of her body and physical superiority over Blu. By further shifting power relations and elevating the Brazilian women she represents, Jewel occupies the

\footnotetext{
${ }^{9}$ Canelo develops this point in a study of the GNP star Carmen Miranda, correlating the Policy's marketing-oriented sexualization of the South American woman and excessive accumulation. She was sent to the US in 1939 by Brazilian President Vargas, also at the invitation of American producers, to foster ties between the northern and southern hemispheres, also at the invitation of American producers. The exotic hat that she popularized in the seven-minute piece The Lady in the Tutti-Frutti Hat, within the musical The Gang's All Here (US, Busby Berkeley, 1943) still figures in the logo of American fruit companies. Saldanha acknowledged his debt to this star through a strong visual allusion to Miranda with the helpful mechanic Luís wearing her signature hat in the animation's long Carnival scene.

${ }^{10}$ This stereotype has in fact, has been part of the world's imaginary of the country for centuries. For example, as far back as 1500, Pero Vaz de Caminha, the scribe of Portugal's first maritime expedition to Brazil, wrote a letter to the king of Portugal infused with expressions of desire for the land and its women.
} 
position of command over Blu's awkward movements. This is, however, a brief deviation from the animation's predominant North-South hierarchies (see below): the US-raised flightless partner remains on top (Figure 9).

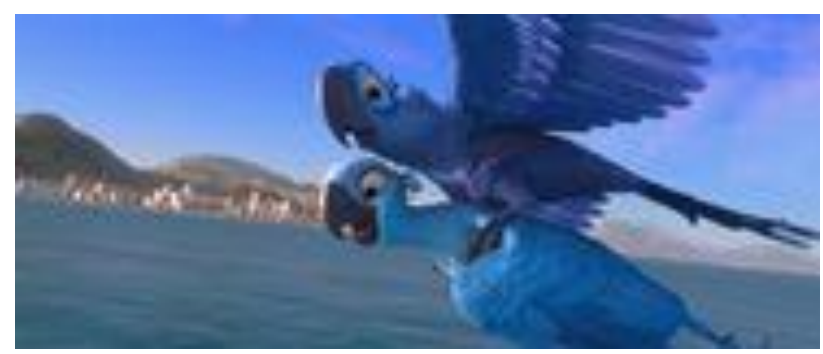

Figure 9: Jewel's Female Superiority Source: Fandom Wiki Rio 2014

Sexual undertones in Saldanha's animation also approximate it to the GNP's projection of Rio as a tropical paradise to be consumed. It is common for an animation to convey subliminal sexual messages, targeting humor for the parents who are watching it with their child (Bendazzi 1995). Humor thus combines with stronger sexual innuendos in his stereotypical display of the eroticism of Rio's beaches. The hang-glider sequence ends with Blu and Jewel landing on a touristy beach by bouncing off the backside of a curvy woman in a yellow bikini. The frame focuses on her erotically drawn behind, leaving no doubt that this is not simply humor for children (Figure 10).

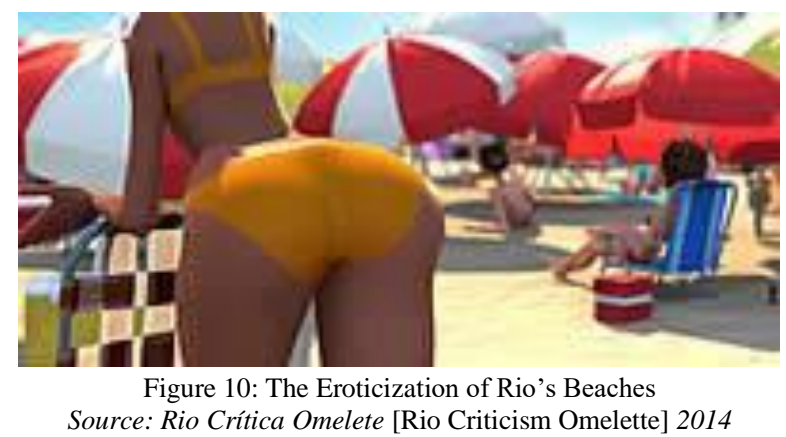

The landing scene is also an occasion for the movie to market Rio's beach sportsmanship through volleyball games. Emphasis is also placed on the city's trademark dental floss, a figurative term for the Cariocas' tiny bikini used by Cariocas, which is so thin that it goes between the woman's buttocks. This is later depicted in a Carnival scene, sexualizing a Brazilian dentist wearing it; using a humorous pun, she tells her client not to forget to use the dental floss.

\section{Technology Versus Nature: Reinstating the GNP's North-South Hierarchies}

Waldilene Miranda (2014) has spotted a stereotyped foreign look pervading Rio's narrative. Homi Bhabha, in turn, theorized on the ambivalence of the stereotype, vacillating as it does between affirmation and disavowal in the construction of otherness (1994). ${ }^{11}$ Indeed, Saldanha's focus on Rio's assets, in itself laudable, loses its effectiveness through the movie's projection of hierarchical

\footnotetext{
${ }^{11}$ Bhabha says: [T]he stereotype ... is a form of knowledge and identification that oscillates between what is always" in place," already known, and something that must be anxiously repeated... For it is the force of ambivalence that ... ensures its repeatability in changing historical and discursive conjunctures... produces that effect of probabilistic truth and predictability which, for the stereotype, must always be in excess of what can be empirically proved or logically construed (1994, 66).
} 
oppositions between the North and the South: technology/nature, reserve/exuberance, rationality/sensuality, mind/instinct, discipline/fun, and order/disorder.

Rio's lush and colorful forests sharply contrast with monochromatic Minnesota (labeled "Not Rio"), where the tropical bird is domesticated (Figure 11).

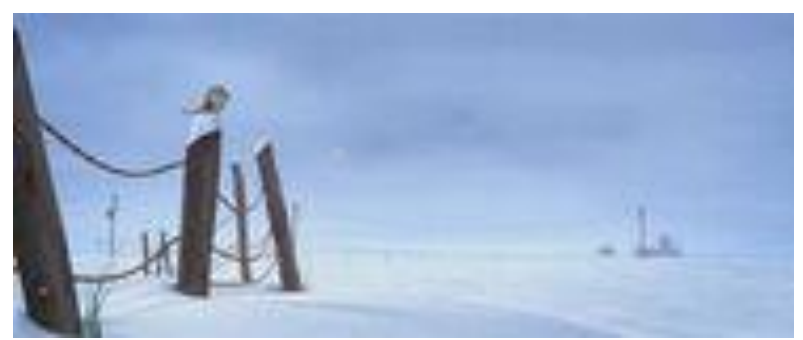

Figure 11: Monochromatic Minnesota

Source: Fandom Rio 2014

Minnesota's birds are portrayed as ordinary, plain, lethargic, and rude to the protagonist, while Brazil's birds are instinctively protective. A Brazilian toucan who thinks Blu is too rational ("you think too much"), helps him bring his dormant flying instincts to life. In further contrast with Blu, who has lost his instinctive capacities, flying in Brazil's forests is freedom for the female macaw, Jewel.

Rio's urban forests, however, are ambiguously projected as a site where bird traffickers commit their crime. In further contrast, the house Blu shares with Linda in Minnesota can be described, in Roberto DaMatta's terms, as "a place of comfort and security where things move in a predictable, smooth trajectory [...] within a regular and methodical work ethic" $(1992,83)$ which extends to the library where Linda works in Blu's company. Brazil is typecast as a natural haven, the North as technological, and a beacon of efficiency. Blu clearly embodies the stereotype of Americans as technologically skilled; his well-equipped daily routine in Minnesota includes turning on the toaster for Linda and cleaning his teeth with a toothbrush (Figure 12).

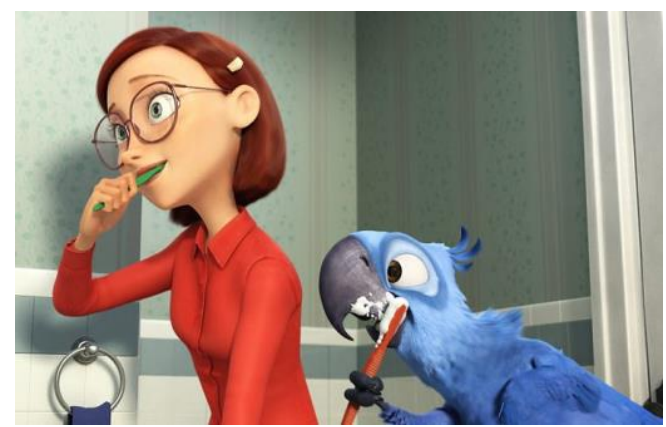

Figure 12: Blu's Hygienic Habits

Source: Adoro Cinema [I adore cinema] 2011

He saves time by sliding down the staircase banister and driving around the house in a toy car. Instead of flying, the intellectualized bird reads flight fundamentals from a book, locates Rio on the globe, makes complex mathematical operations with a calculator, and mediates his contact with other birds by the cable TV series Animal Planet (Figure 13). 


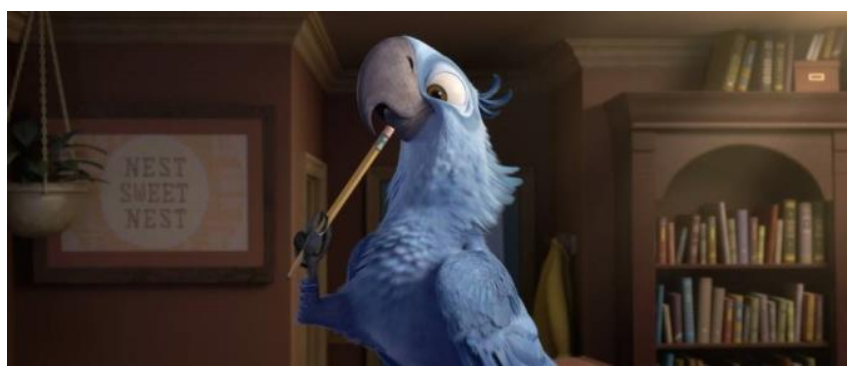

Figure 13: An Intellectualized Bird Source: Veja Magazine 2011

In geopolitical terms, Saldanha's Manichean aesthetics reinstate asymmetries between the two countries in technological innovation and development. His images reinforce what sociologist Fernando Henrique Cardoso (1989) has punctuated as Brazil's/Latin America's incorporation into the globalized world as a minor partner and within the constraints of a dependent relationship. It stands to reason that this projection contradicts the historical moment of Brazil's leading role in the G20 and rising profile as a BRICS country.

\section{The GNP Repositioned: Inconsistencies in the Aspiring Global City}

Brazil's subordination to global dynamics has intensified its spatial and social divides and accentuated the historical unequal labor opportunities that gave rise to precariously integrated social actors. ${ }^{12}$ Luiz C. Ribeiro and Edward Telles, in turn, pointedly anticipated that "globalization in Rio de Janeiro might create greater distance between those integrated in the new economic order and the excluded" $(2000,94)$. In response to those who have brought Saldanha to task for dispelling Rio's negative aspects before they reach global visibility, this section explores his achievements in projecting social tensions around competing forces of order and disorder, including stateneglected orphan children, precarious labor integration, and transnational criminality. Downsides in this inherently positive move are also analyzed.

\section{(Mis)Quoting Disney: From a Playful Improvisor to "Malandros” and Criminals}

Upon his return from a long GNP-sponsored visit to Rio, Disney created the travelogue Aquarela do Brasil [Watercolor of Brazil] (1942). This is one short from the package film Saludos Amigos [Hello Friends] (1942), which was followed by The Three Caballeros (1943). Aquarela do Brasil begins with a celebration of the city's vibrant nature and beacons to the world (the Sugar Loaf, the Christ). Disney's paintbrush then creates the parrot Joe Carioca, a visual symbol of the NorthSouth encounter; he boasts green and yellow plumage (Brazil's national colors) and a red and blue tail (the colors of the American flag) (Figure 14).

\footnotetext{
${ }^{12}$ Sassen indeed underscored the complexities of competitiveness in global cities, as the growing number of high-level professionals increases socio-economic inequality rises for those less able to compete in the demand for specialized skills (2001).
} 


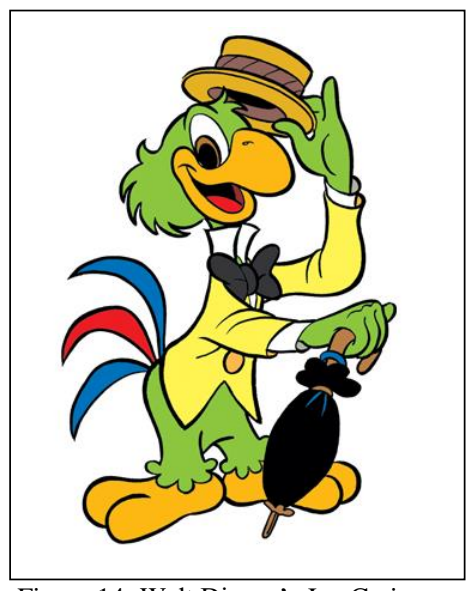

Figure 14: Walt Disney's Joe Carioca

Source: Comic Vine 1942

Donald Duck arrives in Rio, produces a postcard from Hollywood, and the tropical bird welcomes and befriends the American visitor, encouraging him to wander around the cityspectacle and enjoy Rio's carefree lifestyle. Technicolor features produced during World War II, a watershed moment for the emergence of the US as a global superpower, often "map the region in terms of US desires" (Spellacy 2006, 62). Accordingly, Joe Carioca introduces Donald Duck to the typical Brazilian drink, cachaça, presumably to enhance the city's tourist attractiveness of available drink for Post-Prohibition Americans. In the final sequence, the two dance the samba in great harmony, visually cementing the GNP's intended cultural approximation of the two countries (Canelo 2014) and projecting Rio's hedonism. Witty, outgoing, and playful Joe Carioca is also a great improviser who ingeniously adapts to difficult circumstances, transforming precariousness into useful instruments, for example, his umbrella into a guitar.

Disney, again by virtue of his allegiance to the GNP, does not specify the parrot's social context. He is simply a Carioca. However, Joe Carioca's "way of walking, singular dressing... seductive mode of speaking... skill and liveliness" (DaMatta 1992, 209) displays several traits of the Brazilian folkloric malandro, a moneyless loafer who lives on luck, wits, informal chores, parasitism, or petty thieving. Unlike Disney's, Saldanha's malandros are firmly rooted in Brazil's social structure, confirming the persistence during Rio's economic upsurge of "competing realities and social ethics in the struggle against poverty and the injustice of a context of almost impossible social mobility" (Novinger 2004, 114).

Luminary Brazilian cultural theorists Antonio Candido (1995) and Roberto DaMatta (1992) have theorized on malandragem/malandroism as a culturally derived defense against the rigidity of the race-class system in Brazil. The malandros originated in the $19^{\text {th }}$ century, when a monarchy, a nobility, and an administration transplanted from Portugal to Rio encountered a city of predominantly black slaves. The malandros, making up the cohort of few free men, had little or no work and lived on informality, typically gambling and deceiving those less clever than they, neither totally opposing nor submitting to the demands of the world of order.

Saldanha does not venture into Rio's attenuated but still dark territory of very young impoverished children swept into the drug trade, as in City of God. However, he includes two types of malandros as well as criminals, absent from Disney's movie. He is given credit firstly for creating a social plot and addressing the ethical dilemmas of the orphan boy, Fernando. This intrinsically innocent child, trying to escape from an unjust and limited social situation, touches the boundaries of malandroism, stealing rare birds for traffickers as a survival strategy. In the most poignant scene, the boy is turned away by the bird dealers, even after he exclaims, "I don't have a mama," and "I just needed the money." However, Fernando acts both as a representation of 
malandroism and as the vessel of eventual redemption from petty crime, symbolizing Rio's road to recovery.

The witty and seductive marmosets, with a talent for fooling and exploiting people, represent a second type of malandros: those who engage in petty theft but are not downright criminals. This type fits into DaMatta's description of the malandro as one who, using seduction as a survival strategy, slips in and out of high society, always hoping for upward mobility, while utilizing "the typical weapons of the weak [...], deceiving or outwitting people in social positions of power and prestige [and] transforming every disadvantage into an advantage" (1992: 214-218). The marmosets ensure they do not move down the social ladder, hanging around the upper-class American tourists and breaking into dance to distract them while some other monkeys steal their valuables. The malandro's actions are assessed through the prism of efficacy (Candido 1995); accordingly, in a humorous scene, the marmosets energetically dance, wearing stolen watches around their waists (Figure 15).

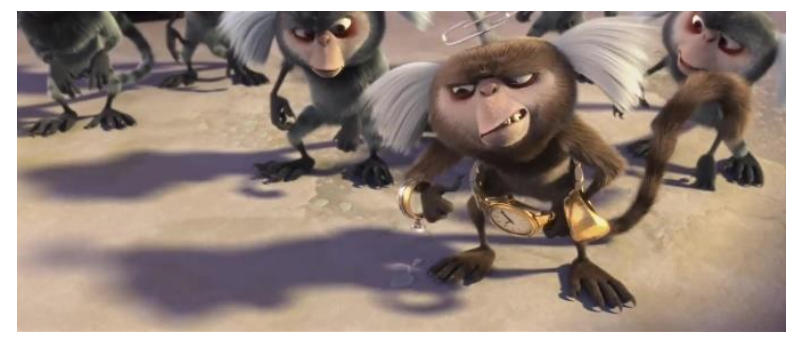

Figure 15: The Marmosets Dancing with Stolen Watches Source: Fandom Rio 2014

As malandros learn nothing from experience, the marmosets involve themselves in the monkey business of helping the traffic leader, Marcel, capture the blue macaws, bringing disorder into the paradisiacal forest where their illicit work remains out of the law's reach. On the other side of the spectrum are the traffic leaders, clearly professional criminals.

Saldanha both deploys and neutralizes social tensions. Presumably to accommodate the animation's marketing purposes and family audiences, he offers a spin on Rio's at the time improved but lingering organized crime. A degree of separation is also formed as humans and cute birds are shifted away from the violence of drug traffic in the city. It is Nigel, an ugly criminal bird assisting the smugglers, who has violent interactions with other birds. By also incorporating animals, subconsciously associated with endearing appearances, and more enjoyable to viewers, especially children, Saldanha softens the perception of petty crime in his hometown.

He does even less well in his typecasting by reinforcing perverse correlations between racial inequality and criminality in Rio. During the city's previous weakened economic dynamism, income concentrated in an $80 \%$ white region while poor neighborhoods concentrated a less educated population of mostly Afro-Brazilian descendants (Ribeiro and Telles 2000). Despite Brazil's affirmative action since 2001 and the creation of the Special Secretary for the Promotion of Racial Equality Policies in 2003, Saldanha's images cement the race-crime correlation. The brown marmosets commit petty thievery, while the colorful creatures of the urban forest are the non-criminal creatures. He also projects light brown and curly-haired Fernando, who temporarily steals birds for dealers (Figure 16). 


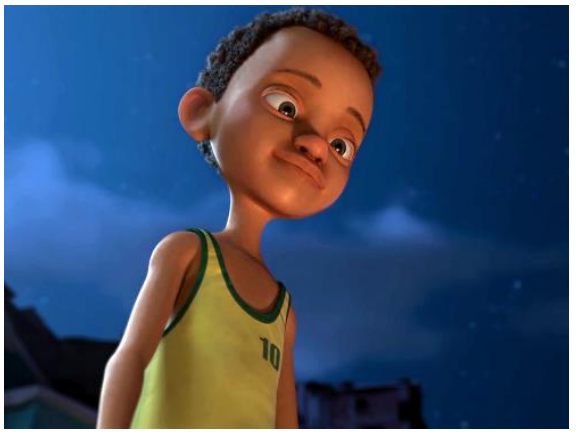

Figure 16: Favela Orphan Boy Fernando Source: Fandom Rio 2014

The animation unequivocally deploys the trafficker Marcel and his helpers as Afro-Brazilians (Figure 17).

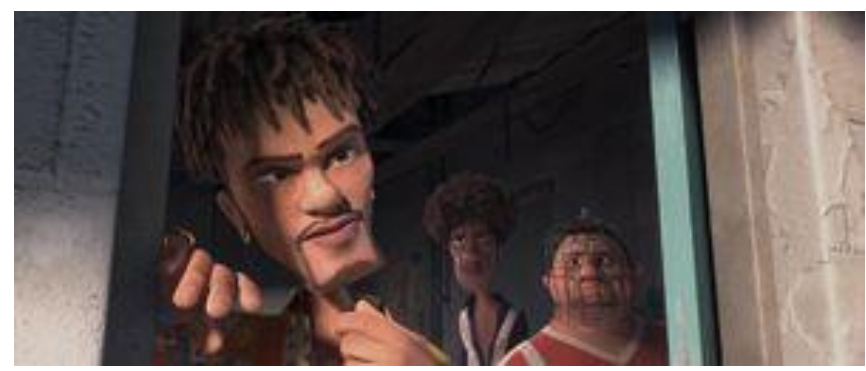

Figure 17: Marcel, a Bird Trafficker, and His Helpers Source: Fandom Rio 2014

A related downside is the race-oriented salvationist ideology that reinforces power asymmetries between the Northern and the Southern Hemispheres. Anthony Ciancone (2016), drawing upon Minako Maykovich's work on the ways in which white Americans are racially perceived (1972), has raised further problematic nuances in the movie's stereotypical projection of racial identities and, particularly, of Fernando's adoption by Linda and Túlio. Linda's righteous and generous move, besides outweighing her stereotypical white Americans' ignorance of other cultures (in itself a priori controversial), is reminiscent of the noble and generous white savior who rescues natives, a trope often used throughout literature and movies (Hughey 2010). Ornithologist Túlio, a white Brazilian, somewhat falls into the same stereotype, at the same time reaffirming traditional notions of white men being the intellects of society.

\section{Repositioning the GNP: Branding Favela Tourism and Rio's Carnival}

The demographic transition of most of the world's urban population to the Southern hemisphere has shifted the focus of urban studies to the complex realities of the Global South (Parnel and Robinson 2013). Rio reflects the urban processes of the Global South metropolises, a context in which the study of favelas has gained currency among urbanists. Favelas are urban agglomerates of self-built houses, disposed in general in a disordered and dense form, and in general lacking public and private essential services (Jovchelovitch and Priego-Hernández 2013, 38). Rio's favelas started in the $19^{\text {th }}$ century. The first, the Providência favela, which replaced the city's tenements, was built in 1897 by veterans who, upon their return from the Canudos war, faced the government's unfulfilled promise of a house as a reward for their victory. Freed African slaves who were denied reabsorption into white Brazilian society further "created territorial and epistemological 
communities for themselves as a consequence of their subordinate locations within the bourgeois public sphere" (Hanchard 1999, 61).

The city's favelas sprawled after 1960, in part due to a fast-growing population and rapid industrialization, and its over one thousand communities, as favelas are called in recent years, are home to one in five Cariocas (Barbassa 2015). Cidade Partida [Broken City] is a label that insistently challenged Rio's celebratory sobriquet Cidade Maravilhosa (Carvalho 2016) ${ }^{13}$. In the neofavelas, characteristic of the late $20^{\text {th }}$ century, Afro-Brazilians and poor residents disproportionately suffered from an absence of basic human rights, the decline of the old associative fabric, and perverse forms of sociability largely brought about by the violence associated with the drug trade and armed conflicts between drug traffickers and the police (Ribeiro and Telles 2000).

Rio's production was during the city's euphoric years, which included concerted and somewhat successful efforts by authorities and local grassroots groups to improve the quality of urban life (Jaguaribe and Salmon 2016). Various measures, notably the ambitious pacification policy that started in 2008, targeted Rio's communities. ${ }^{14}$ Even though there was also some upgrading of many of Rio's favelas, the "broken city" syndrome persisted. In order to overcome the syndrome and to approximate the favelas to the cinematic Southern Zone, since the 1990s favela dwellers themselves have started exploring their touristic potential (Jaguaribe and Salmon 2016). Favela tourism first started in 1992, when delegates to the United Nations Summit on the Environment were taken to Latin America's largest one, Rocinha. Residents developed tour attractions also by capitalizing upon celebrities' initial interest in favelas. These include Michael Jackson (1996), who awarded international recognition to the Santa Marta favela by recording “They Don't Care About Us" there. In 2011, Barak Obama visited the stigmatized community of Cidade de Deus [City of God]. US Vice-President Joe Biden was another who conferred a "tinge of celebrity aura" to Rio's favelas (Angelini 2020, 23).

One way in which favela tourism has become part of the city's cultural industry is through community-led initiatives. Many residents view this type of tourism as opportunities to debunk favela stigma and to boost their collective self-esteem by showing positive sides of their community. These tours, usually on foot, in small groups and with a local guide, enable closer contact with the residents, who are thus given the chance to speak for themselves, to control the way they are represented, and to provide an insider's view of the history and cultural potential of the favela (Bourdehoux 2016).

Saldanha captures the boom of the phenomenon in the years preceding the mega-events. His favela branding, however, differs from the profile-raising community-led initiatives. It resembles private for-profit motorized tours, organized from outside the favelas mostly for middle- and upper-class tourists (Bourdehoux 2016). This type of tourism prevents contact between visitors and residents who also tend to perceive them as intrusive. Such is the case of Linda and Túlio's thrill as they race up the narrow favela alleys on a motorcycle. Again, as a display of the US superiority, more technological Linda takes over the driving from Túlio to speed the ride up to reach the stolen birds. Noteworthy is that Saldanha, in his spin on the drug trade, reinstates projections of the favelas as stockpiling points for smuggled goods, as is the case with cocaine (Penglase 2011).

Saldanha's apparently progressive inclusion of this social space sits uneasily with his

\footnotetext{
13 The term was coined by the journalist Zuenir Ventura in 1994.

${ }^{14}$ The term Pacificação [Pacification] has gained wide currency in Brazilian Studies. It relates to the Unidade de Polícia Pacificadora (Police Pacification Unit, or UPP), "a program launched in 2008 [...] administered by the State of Rio de Janeiro's Military Police force [...] It represents a significant departure from previous policing and policy strategy in favela neighborhoods. The explicit aim of the program is to physically reclaim territory-exclusively in Rio's urban favela communities - from drug trafficking gangs by force of arms and place the favelas under the control of the state authorities through the imposition of a Police Pacification Unit in the community" (Jaguaribe and Salmon 2016, 40).
} 
projection of significant wealth disparities. Evan Sellinger (2009), in his discussion of the ethics of ever-blooming slum tourism, has stressed how profit-oriented tours promote negative dramatization of difference, an approach he identifies as poorism. The favela is showcased as an adventure for the white American, having time and disposable income, to seek her prized bird. In contrast, as Anthony Ciancone (2016) notes, in an emotional scene, poverty-stricken orphan Fernando wanders from favela rooftop to favela rooftop, picking up any scraps he can on his way to what, in a very loose sense, can be called home. Fernando's seems to be merely a partially covered space on a zinc rooftop, with minimal possessions and a blanket for him to sleep upon.

It could be the case that, Saldanha's intention when showing Fernando sleeping peacefully on the rooftop is to project the achievements of pacification, which enabled favela tourism to blossom. By the same token, the favela is also represented as a relatively uncomplicated space of optimistic city dwellers, content with their life situations and stereotypically hypnotized by football and Carnival, oblivious to Brazil's and the city's wealth concentration. However, the divide between the haves and the have-nots deepens as he feeds international audiences with stereotypes of poverty. Housing defines this society in the animation, and complex lives are reduced to economic status. For Ciancone, inter alia, it is also difficult not to notice his aestheticization of the favelas. They are beautifully represented as a mass of little houses, all cozily stacked among each other on the mountain from where Fernando looks out on a twinkling city below (Figure 18).

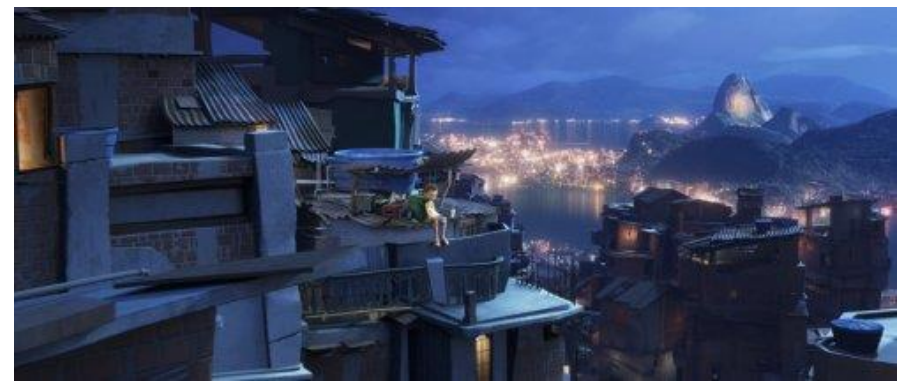

Figure 18: Orphan Fernando at His Home in the Favela, Overlooking the City Source: Rio Uma Visão Sobre o Brasil-Blogspot [Rio A View on Brazil - Blogspot] 2012

In short, there is realism in his inclusion of diminished but lingering poverty. However, there is also a degree of imagineering as the favelas are projected as picturesque places to climb and enjoy their privileged view of the city. However, the smallness of the lives of the impoverished and their separation from the upper classes stand out as Fernando watches their unreachable wealth from above.

\section{Carnival and the Dilution of Spatial and Social Divides}

"As cities compete to position themselves in the global flows of capital [...] promotional strategies include its culture and the potential for aspects of its culture to attract tourism" (Rennie-Short 2004, 23-24). Rio's imagineering particularly emphasizes dancing and the spectacle of Carnival, which was created in minutest of detail. The birds' immense heart-shaped red chests turning into drums for the samba beats suggest that powerful emotions and dance are in the Carioca blood. In the flamboyant initial sequence, three birds are dancing even before they are hatched, and baby Blu is surprised at seeing his tail instinctively twitching to samba rhythms. The birds' flight quickly turns into a kaleidoscope of colorful tropical plumage, emulating the choreography of the samba schools in the urban areas during Carnival, a festival explored at length in the movie. 
Rio's spatial and social divides are particularly neutralized in the movie through a marketing focus on Carnival. As such, it presents Rio to the world as a Cidade Integrada [Integrated City], an Olympics-derived sobriquet that insightfully pushes back against the broken city epithet (Carvalho 2016, 23). DaMatta (1992) theorized on the socio-spatial changes during the ritual of Carnival. The city, perceived in everyday life as "a highly fragmented, problematic megalopolis," "suddenly finds itself articulated into a communitas of encounter" $(1992,87)$. A major distinctive trait of Rio's Carnival is its "harmonization of inequality," when "the boundaries that compartmentalize groups and categories are suspended," and "the social world ceases to be organized around the ordinary social classifiers of occupation, wealth, power, etc." (DaMatta 1992, $42,123,126)$. There is also an egalitarian structure in the samba schools and particularly in their parades that bring together poor favela people, celebrities, and media stars. DaMatta sums it up; Rio's Carnival can be understood as "the symbolic empowerment of those who have nothing" $(1992,42)^{15}$.

Through visual excess, Rio highlights an integrated city with multiple parties occupying all the spaces (the forest, the urban center, and surrounding areas). Everyone joins in the merriment and reinvention of the city space. Through this ritual of transformation, the dentist is no longer defined by her profession, but by wearing dental floss bottoms and samba dancing. In the increased freedom and anonymity of Carnival, shy and reserved Linda, now bikini-clad on a float, overturns the North-South hierarchies joining the samba school parade and using this moment of encounter with merriment to trace the blue macaws (Figure 19).

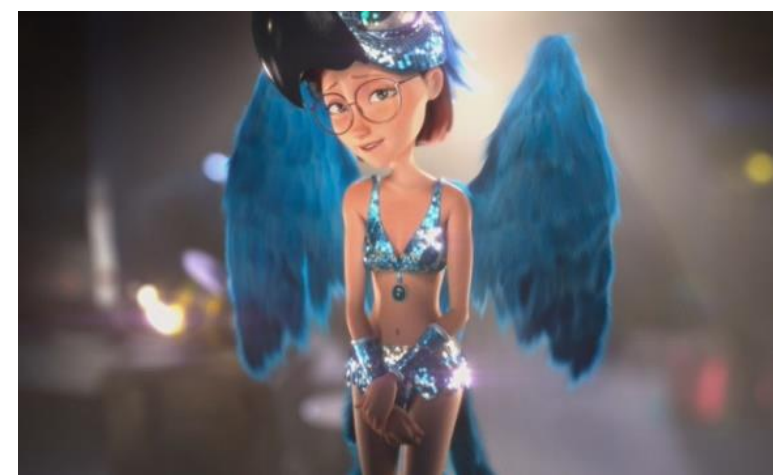

Figure 19: Bikini-Clad Linda on a Carnival Float Source: Deviant Art 2014

Carnival is also a moment of liberation: the blue macaws unchain themselves and escape; a group of wise-cracking city birds help Blu find the courage to spread his wings and follow his destiny. The yellow canary Nico, who makes friends with and takes Blu to the next level, sums up: "Liberdade, muita dança é o que interessa." "Eu quero festa e samba" ["Freedom and plenty of dancing is what counts. I want partying and samba"]. ${ }^{16}$

\section{Conclusion}

15 Several scholars, including DaMatta (1992), have analyzed the year-long investment of favela people in preparation for the Carnival parade, including sacrifices to make their nobility costumes.

\footnotetext{
${ }^{16}$ Marsh, in line with the GNP and the film's theme of survival of species, brings out the impact of Rio on Linda's sexuality: "As an unattached female who dislikes leaving her home, Linda seems to present her own threat to the survival of the human species. Fortunately, all she needs is a little time below the equator to bring out her sensuality" $(2012,75)$.
} 
Saldanha's symbolic reinvention of Rio in the global imaginary coalesces with the major goal of the city's administration, which is to prepare it for a new era of urban competitiveness and for world capital (Marcuse and van Kempen 2000). Topicality also marks his Rio, which offers a vision of a new moment in geopolitics, evident in the recalibration of urban studies to the physical, social, and economic realities of cities in the Global South. Major technological developments and a big studio behind him opened a global market for his fortunate choice of the animation genre with its inherent capacity to cross borders and reduce big themes to an experience shared by different ages, cultures, and languages. In this way, his so-called "love letter to his hometown" aligns with Rio's administration branding campaign where "the tourist industry, real estate developers, and advertising agencies unleashed desirable images of the city for purchase and consumption" (Jaguaribe and Salmon 2016, 32). His proud statement reveals the marketing ploy underlying the love declaration:

The city may spend billions of dollars advertising about Rio, but none will have Rio's reach. It is numerically impossible. It was my lifetime gift to the city. Now, it's up to them, the government and the local people, to figure out what to do with my full-scale declaration of love for Rio. The city is on the map more than ever, and if you look closely, all the characters in the movie treat Rio with great affection, just the way I would like to see it happen in real life (In Graça 2014, n.p.).

His affective geography originally and authentically brings out many positive and less publicized aspects of Rio, such as the urban forests and their fauna. He should also be complimented for portraying favelas and the survivors of precarious social integration in the globalizing city. His contribution should be particularly credited for creating a social plot that brings to light an unjust society and socio-spatial hierarchies that govern the city's everyday life, albeit allayed through his marked focus on Carnival that overturns them.

His reliance on intrinsically ambivalent stereotypes, however, can be a double-edged sword. His stereotype-consistent associations between race, petty thieving and criminality cast a shadow over the city he seeks to promote. His GNP-derived stereotypes for Rio may have reached a wide public, particularly Americans, and promoted tourism to the city. He may have been successful with ecotourism. However, his ethics in incorporating what can be perceived as poverty voyeurism is minimally controversial. It also goes right up against the local residents' profile-raising initiatives of community-led favela tourism. In macro-context terms, his updating of stereotypes to another historical context persistently reinstates anachronic power hierarchies between the North and the South while further casting Brazil in the periphery of global capitalism. Paradoxically, this is exactly when Brazil was taking up a leading role in the G20, emblematic of the upturning of the G7 hegemonic structures of capitalism (Cervo 2008). It is also when, correlating with the preOlympics Rio's aspirations to global urban competitiveness, the emergence of the BRICS signaled a recalibration of the world's economy.

The movie was launched before the protests that occurred prior to and during the World Cup and the Olympics. The protests bore evidence to the astronomical costs of hosting mega-events compared to the mixed achievements and small benefit to citizens. The mega-events, intrinsically a window of opportunity for what Sarkar (2014) has labeled "a transformative South," ultimately revealed the fault lines in the Global South. Recently launched productions open the way for further studies of the contrast between Saldanha's intended celebration of his hometown's vibrancy and sense of joy and the later reality of tears.

\section{REFERENCES}


Andersson, Johan, and Lawrence Webb. 2016. Global Cinematic Cities: New Landscapes of Film and Media. Columbia University Press. doi:10.7312/ande17746.

Angelini, Alessandro. 2020. "A Favela That Yields Fruit: Community-Based Tour Guides as Brokers in the Political Economy of Cultural Difference." Space and Culture 23 (1):1533. doi:10.1177/1206331219865694.

Barbassa, Juliana. 2015. Dancing with the Devil in the City of God. New York: Touchstones.

Bendazzi, Giannalberto. 1994. Cartoons: One Hundred Years of Cinema Animation. Bloomington and Indianapolis: Indiana University Press. doi:10.5860/choice.32-4401.

Bhabha, Homi K. 1994. The Location of Culture. Oxford: Routledge. doi:10.4324/9780203820551.

Broudehoux, Anne-Marie. 2016. "Favela Tourism: Negotiating Visitors, Socio-Economic Benefits and Representation in Pre-Olympics Rio de Janeiro.” In Protest and Resistance in the Tourist City, edited by Claire Colomb and Johannes Novy, 191-209. London: Routledge.

Candido, Antonio. 1995. "Dialectic of Malandroism." In On Literature and Society. Princeton: Princeton UP, 179-103. doi:10.1515/9781400863983.79.

Canelo, Maria José. 2014/2. "Producing good neighbors: Carmen Miranda's Body as Spectacular Pam-Americanism." Revue Française d' Études Américaines [French Journal of American Studies] 139: 6-76. doi:10.3917/rfea.139.0060.

Cardoso, Fernando Henrique. 1989. "Associated-Dependent Development: Theoretical and Practical Implications." in Authoritarian Brazil: Origins, Policies and Future, edited by Alfred Stepan, 299-326. New York: Oxford University Press.

Carvalho, Bruno. "Introduction. Rio, City of Epithets: Olympic Urbanism in Context." In Occupy all Streets: Olympic Urbanism and Contested Futures, edited by Bruno Carvalho, Mariana Cavalcanti and Vyjayanthi Rao Venuturupalli, 20-29. New York: Terreform.

Cervo, Amado Luiz. 2008. Inserção Internacional: formação dos conceitos brasileiros [International Insertion: The Formation of Brazilian Concepts]. São Paulo: Editora Saraiva.

Ciancone, Anthony Michael. 2016. Rio de Janeiro's Contemporary Social Tensions. Unpublished paper. London: Queen Mary University of London.

DaMatta, Roberto. 1992. Carnivals, Rogues and Heroes: Interpretation of the Brazilian Dilemma. Translated by John Drury. University of Notre Dame Press.

Denslow, Philip Kelly. 1997. "What is Animation and Who Needs to Know? An Essay on Definitions." In A Reader in Animation Studies, edited by Jayne Pilling, 2-7. Sydney: John Libbey \& Company Pty Ltd.

Fitzmaurice, Tony, and Shiel, Mark (eds). 2001. Cinema and the City: Film and Urban Society in a Global Context. Oxford Blackwell Publishers. doi.org/10.1002/9780470712948.ch2

Fontaine, Jean-Jacques. 2016. Rio de Janeiro e os Jogos Olímpicos: Uma Cidade Reinventada [Rio de Janeiro and the Olympic Games: A Reinvented City]. Curitiba: Editora Prisma.

Fridmann, Mandy, and Carolina Moreno. 2014. "Carlos Saldanha: 'Rio' Movies Began from My 'Need To Show A Different Brazil." Huffington Post, April 11, 2014: n. p. $<$ http://actionnews.ca/newstempch.php?article=/2014/04/11/carlos-saldanhario_n_5132922.html>. Accessed August 17, 2019.

Graça, Eduardo. 2014. "Rio 2 é sobre nossas escolhas. Entrevista com Carlos Saldanha [Rio 2 is About Tour Choices]. Interview with Carlos Saldanha. Carta Capital [Capital Letter], 28-03.

Hanchard, Michael George. 1999. Racial Politics in Contemporary Brazil. Durham: Duke UP. doi.org/10.1215/9780822382539.

Hughey, Matthew W. 2010. "The White Savior Film and Reviewers' Reception." Symbolic Interaction 33 (3): 475-496. doi.org/10.1525/si.2010.33.3.475. 
Jaguaribe, Beatriz and Scott Salmon. 2016. "Branding the Marvelous City." In: Occupy all Streets: Olympic Urbanism and Contested Futures, edited by Bruno Carvalho, Mariana Cavalcanti and Vyjayanthi Rao Venuturupalli, 30-58. New York: Terreform.

Jovchelovitch, Sandra. 2013. Underground Sociabilities: Identity, Culture and Resistance in Rio's Favelas - Rio de Janeiro: Wonderful City, Broken City. UNESCO.

Koche, Thiago. 2011. Rio (Carlos Saldanha, 2011). RUA (Revista Universitária do Audiovisual) / [RUA (Audiovisual University Journal)]. Maio [May]. <http://www.rua.ufscar.br/riocarlos-saldanha-2011/>. Accessed August 13, 2019.

Marcuse, Peter and Ronald van Kempen. 2000. "Rio de Janeiro: Emerging Dualization in a Historically Unequal City.” In: Globalizing Cities: A New Spatial Order? Massachusetts: Blackwell.

Marsh, Leslie L. 2012. Another Good Neighbor? Hollywood's (Re)embracing of Brazil in Rio (2011) and Fast Five (2011). Revista Canadiense de Estudios Hispánicos [Canadian Journal of Hispanic Studies]. 37 (1):67-85. <https://jstor.org/stable/24388781> Accessed November 28, 2019.

Maykovich, Minako Kurokawa. 1972. "Reciprocity in Racial Stereotypes: White, Black, and Yellow." American Journal of Sociology 77 (5): 876-897. Accessed March 29, 2020. www.jstor.org/stable/2776927.

Mehr, Linda H. 2000. "The Way We Thought We Were: Images in World War II Films." In The Way We Really Were: The Golden State in the Second Great War, edited by Roger W. Lotchin, 30-46. Urbana and Chicago: University of Illinois Press.

Meirelles, Fernando. 2002. City of God.

Miranda, Waldilene. 2014. Representações identitárias do imaginário nacional: miradas acerca do filme Rio, de Carlos Saldanha [Identity Representations of the National Imaginary: Views on the Movie Rio, by Carlos Saldanha]. Unpublished paper. Juiz de Fora: Universidade Federal de Juiz de Fora [The Federal University of Juiz de Fora].

Mulvey, Laura. 1989. "Visual Pleasure and Narrative Cinema." In Visual and Other Pleasures, edited by L. Mulvey, 6-18. London: Macmillan. doi.org/10.1007/978-1-349-220984_25.

Novinger, Tracy. 2004. Communicating with Brazilians: When "Yes" Means "No." Texas, USA: University of Texas Press.

Padilha, José. 2007. Elite Squad.

Parnell, Susan and Jennifer Robinson. 2013. "(Re)theorizing Cities from the Global South: Looking Beyond Neoliberalism.” Urban Geography 33 (4): 593-617. doi: 10.2747/02723638.33.4.593.

Pilling, Jayne, ed. 1997. A Reader in Animation Studies. Sydney: John Libbey \& Company Pty Ltd.

Penglase, R. Ben. 2011. "Lost Bullets? Fetishes of Urban Violence in Rio de Janeiro, Brazil." Anthropological Quarterly, 84 (2): 411-438. Accessed March 29, 2020. www.jstor.org/stable/41237500.

Ribeiro, Luiz César de Queiroz; Telles, Edward. 2000. "Rio De Janeiro: Emerging Dualization in a Historically Unequal City." In Globalizing Cities: A New Spatial Order? Edited by Peter Marcuse and Ronald Van. Kempen, 78-94. Oxford: Blackwell.

Rio. 2011. [DVD] Greenwich, Connecticut, USA: Carlos Saldanha.

Rodrigues, Antonio. 2008. O Rio no cinema / Rio in Movies. Rio de Janeiro: Nova Fronteira.

Robinson, Jennifer. 2002. "Global and World Cities: 'A View from off the Map."” International Journal of Urban and Regional Research. 26 (3): 531-54. doi.org/10.4324/9781315684871-9.

Roett, Riordan. 2011. "Brazil's Emergence on the Global Stage." In The New Brazil. Brookings Institution Press. <https://www.jstor.org/stable/107864/j.ctt12818n.12>. Accessed November 28, 2019. 
Russell, Jesse and Cohn, Ronald. 2012. Rio de Janeiro Bid for the 2016 Summer Olympics. Edinburgh: Book on Demand Ltd.

Sarkar, Urvashi. 2014. BRICS: “An Opportunity for a Transformative South?” South Asian Survey, 21 (1-2). doi: 10.1177/0971523115592495.

Schwarcz, Lilia and Heloisa Starling. 2015. Brasil: uma biografia [Brazil: A Biography]. São Paulo: Companhia das Letras.

Schwartz, Rosalie. 2004. Flying Down to Rio: Hollywood, Tourists, and Yankee Clippers. Texas A\&M, University Press.

Sellinger, Evan. 2009. "Ethics and Poverty Tours." Philosophy \& Public Policy Quarterly 29 (1/2): 2-7. http://dx.doi.org/10.13021/G8pppq.292009.109.

Spellacy, Amy. 2006. "Mapping the Metaphor of the Good Neighbor: Geography, Globalism, and PanAmericanism during the 1940s." American Studies, 47 (2): 39-66. doi.org/10.1163/2468-1733_shafr_sim090050072.

The Numbers: Where Data and the Business Movie Meet. 2019. <http://www.thenumbers.com/movie/Rio\#tab=summary>. Accessed August 17, 2019

UNESCO World Heritage List. 2012. Rio de Janeiro: Carioca Landscapes between the Mountain and the Sea. <https://whc.unesco.org/en/list/1100/gallery/\&maxrows=30>. Accessed August 13, 2019.

Ventura, Zuenir. 1994. Cidade Partida [Broken City]. Rio de Janeiro: Companhia das Letras.

Williams, Daryle; Chazkel, Amy and Mendonça, Paulo Knauss de. 2016. "Recent Rio." In the Rio de Janeiro Reader. History, Culture, Politics, 235-245. Durham; London: Duke University Press. doi.org/10.1215/9780822375067-064.

Zimbalist, Andrew. 20015. Circus Maximus: The Economic Gamble Behind Hosting the Olympics and the World Cup. Washington, D.C.: Brookings Institution Press.

\section{IMAGES}

Figure 1: Protective Linda Finds Abandoned Blu. 2014. <https://rio.fandom.com/pt-br/wiki/ Blu?file=Linda_e_Blu1.jpg >. Accessed August 17, 2019.

Figure 2: Poster-Flying Down to Rio in Five Days Via Pan American. https://www.internationalposter.com/product/flying-down-to-rio-in-five-days---viapan-american/. Accessed August 17, 2019.

Figure 3: View of Rio's Urban Forests from a Hang-Glider. 2011.<https://images-na.ssl-imagesamazon.com/images/I/81QxzFTU7ZL._SL1500_.jpg>. Accessed August 17, 2019.

Figure 4: Blu on the Most Beautiful Thing He Has Ever Seen. 2011. https://vejasp.abril.com.br/atracao/rio/. Accessed August 17, 2019.

Figure 5: The Birds' Aerial View of Rio's Iconic Guanabara Bay and the Sugar Loaf. 2011. https://vejasp.abril.com.br/atracao/rio/. Accessed August 17, 2019.

Figure 6: Flying Down to Rio in Airplanes. n.d. <https://finisjhung.com/flying-down-to-rio-onairplanes/. Accessed 08/17/2019.

Figure 7: Aviation and Desire in Flying Down to Rio. 1933 <https://www.alamy.com/flyingdown-to-rio-image 68019568.html>. Accessed August 17, 2019.

Figure 8: Jewel as an Object of Desire. $2014<$ https://rio.fandom.com/wiki/Rio/Gallery?file= BluandJewel4.5.jpg> Accessed August 17, 2019.

Figure 9: Jewel's Female Superiority. 2014 <https://rio.fandom.com/pt-br/wiki/Rio>. Accessed August 17, 2019.

Figure 10: The Eroticization of Rio's Beaches. 2014 <https://www.omelete.com.br/filmes/criticas/rio-critica>. Accessed August 17, 2019. 
Figure 11: Monochromatic Minnesota. 2014 <https://rio.fandom.com/pt-br/wiki/Rio〉. Accessed August 17, 2019.

Figure 12: Blu's Hygienic Habits. $2011<\mathrm{http} / / / \mathrm{www}$.adorocinema.com/filmes/filme146550/fotos/detalhe/?cmediafile=19916325>. Accessed August 17, 2019.

Figure 13: An Intellectualized Bird. 2011. <https://vejasp.abril.com.br/atracao/rio/>. Accessed August 17, 2019.

Figure 14: Walt Disney's Joe Carioca. $1942<$ https://comicvine.gamespot.com/jose-carioca/400534472/issues-cover/>. Accessed August 17, 2019.

Figure 15: The Marmosets Dancing with Stolen Watches. $2014<$ https://rio.fandom.com/ptbr/wiki/Rio>. Accessed August 17, 2019.

$\begin{array}{lllll}\text { Figure 16: Favela } & \text { Orphan } & \text { Boy } & \text { Fernando. }\end{array}$ $<$ https://rio.fandom.com/wiki/Fernando?file=Infobox-Fernando.png $>$ Accessed August 17, 2019.

Figure 17: Marcel, a Bird Trafficker, and His Helpers. 2014 <https://rio.fandom.com/ptbr/wiki/Rio> Accessed August 17, 2019.

Figure 18: Orphan Fernando at His Home in the Favela, Overlooking the City. 2012 <http://rioumavisaosobreobrasil.blogspot.com/>. Accessed August 17, 2019.

$\begin{array}{lllll}\text { Figure 19: Bikini-Clad Linda on a } & \text { Carnival } & \text { Float. } & 2014\end{array}$ <https://www.deviantart.com/zrofrost/art/Rio-Linda-460330415>. Accessed August $17,2019$. 